\title{
EDUKASI PERSIAPAN PERSALINAN DENGAN PROTOKOL KESEHATAN DI MASA KENORMALAN BARU (NEW NORMAL) SEBAGAI UPAYA PENCEGAHAN COVID-19 PADA IBU HAMIL
}

\author{
Aminah Maya ${ }^{1}$, Miskiyah $\operatorname{tamar}^{2}$, Dwita Desti ${ }^{3}$, Fera Chaprilian $^{4}$ \\ ${ }^{1}$ Dosen Prodi D III Kebidanan IKesT Muhammadiyah Palembang \\ ${ }^{2}$ Dosen Prodi Ilmu Keperawatan IKesT Muhammadiyah Palembang \\ ${ }^{3}$ Mahasiswa Prodi D III Kebidanan IKesT Muhammadiyah Palembang \\ ${ }^{4}$ Mahasiswa Prodi Ilmu Keperawatan IKesT Muhammadiyah Palembang
}

Email Korespondensi: mayachabie@gmail.com

\begin{abstract}
ABSTRAK
Kebutuhan asuhan persalinan normal yang diberikan pada pasien tetap perlu di berikan dengan memperhatikan kondisi masih berlangsungnya pandemi COVID-19 serta tindakan yang perlu dilakukan untuk mengatasinya di tingkat keluarga. Pada masa pandemi COVID-19 banyak hal dalam pelayanan kebidanan perlu adanya penyesuaian pelayanan sesuai dengan protokol kesehatan. Permasalahan kesehatan ibu dan anak menjadi hal yang perlu perhatian dalam kesuksesan program-program kesehatan khususnya ibu dan anak untuk menurunkan jumlah angka morbiditas dan mortalitas di tengah pandemic COVID-19. Salah satu kegiatan Pengabdian Masyarakatyang dilakukan adalah "Edukasi Persiapan Persalinan Dengan Protokol Kesehatan Di Masa Kenormalan Baru (New Normal) Sebagai Upaya Pencegahan Covid-19 dan untuk meningkatkan pengetahuan ibu hamil tentang persiapan persalinan di masa pandemi covid-19". Kegiatan ini dilakukan pada tanggal 24-28 Febuari 2021 diikuti sekitar 24 ibu hamil di Kabupaten OKU Timur.
\end{abstract}

Kata kunci: Pendidikan Kesehatan, Persiapan persalinan, Ibu Hamil

\section{EDUCATION FOR DELIVERY PREPARATION WITH HEALTH PROTOCOLS IN THE NEW NORMAL TIME AS A PREVENTING EFFORT OF COVID-19 IN PREGNANT}

\begin{abstract}
The need for normal childbirth care given to patients still needs to be provided with due regard to the ongoing condition of the COVID-19 pandemic and the actions that need to be taken to overcome it at the family level. During the COVID-19 pandemic, many things in midwifery services needed to be adjusted according to health protocols. Maternal and child health problems need attention in the success of health programs, especially mothers and children, to reduce the number of morbidity and mortality rates in the midst of the COVID-19 pandemic. One of the Community Service activities carried out is "Education on Preparation for Childbirth with Health Protocols in the New Normal Period as an Effort to Prevent Covid-19 and to increase the knowledge of pregnant women about preparation for childbirth during the Covid-19 pandemic". This activity was carried out on 24-28 February 2021 followed by around 24 pregnant women in East OKU Regency. Key words: Health Education, Preparation for Childbirth, Pregnant
\end{abstract}

\section{PENDAHULUAN}

Infeksi Novel Coronavirus Disease 2019 (COVID-19) merebak sejak tahun 2019, World Health Organization (WHO) melaporkan virus ini pertama kali ditemukan di Wuhan (Qiao, 2020). Seluruh belahan di dunia kini melaporkan angka kejadian penduduk yang positif terinfeksi COVID-19 termasuk di Indonesia. Situasi berkembang menjadi darurat kesehatan masyarakat secara global (Yang et al., 2020). Terbukti dari 216 negara tercatat yang terkonfirmasi positif COVID-19 sebanyak 17.660.523 dan kasus yang meninggal 680.894 data 28 Agustus tahun 2020 (Gugus Tugas Penanganan COVID-19 RI, 2020). Indonesia melaporkan adanya dua kasus positif untuk pertama kalinya (Maret 2020) (Pradana et al., 2020). Di Indonesia tercatat terjadi peningkatan kasus terkonfirmasi positif sebanyak 3003 menjadi 165.887, yang sembuh mengalami 
peningkatan sebanyak 2325 menjadi 120.900, dan yang meninggal mengalami peningkatan sebanyak 105 menjadi 7.169 kasus (Gugus Tugas Penanganan COVID-19 RI, 2020).

Program pembangunan kesehatan di Indonesia saat ini masih diprioritaskan pada upaya peningkatan derajat kesehatan kesehatan ibu dan anak. Kebutuhan asuhan persalinan normal yang diberikan pada pasien tetap perlu di berikan dengan memperhatikan kondisi masih berlangsungnya pandemi COVID-19 serta tindakan yang perlu dilakukan untuk mengatasinya di tingkat keluarga (ACOG, 2017). Perencanaan persalinan dapat dilakukan manakala ibu, suami dan keluarga memiliki pengetahuan mengenai resiko tinggi dan tandatanda bahaya kehamilan serta bahaya COVID-19. Pada masa pandemi COVID-19 banyak hal dalam pelayanan kebidanan perlu adanya penyesuaian pelayanan sesuai dengan protokol kesehatan. Permasalahan kesehatan ibu dan anak menjadi hal yang perlu perhatian dalam kesuksesan program-program kesehatan khususnya ibu dan anak untuk menurunkan jumlah angka morbiditas dan mortalitas di tengah pandemic COVID-19 (Kemenkes RI, 2020). Cara terbaik untuk mencegah infeksi adalah dengan menghidari terpapar virus penyebab, mentaatiprotocol kesehatan sebagai upaya pencegahan penularan dalam praktik kehidupan seharihari (POGI, 2020).

Ibu hamil tercatat salah satu kelompok rentan resiko terinfeksi COVID-19 dikarenakan pada masa kehamilan terjadinya perubahan fisiologi yang mengakibatkan penurunan kekebalan parsial (Liang \& Acharya, 2020) dan dapat menyebabkan dampak yang serius bagi ibu hamil. Informasi tentang COVID-19 hingga saat ini masih sangat terbatas termasuk data ibu hamil terkonfirmasi positif COVID-19 belum dapat disimpulkan di Indonesia (Pradana et al., 2020). Hasil penelitian dari 55 wanita hamil dan 46 neonatus yang terinfeksi COVID-19 tidak dapat dipastikan adanya penularan vertical dan belum diketahui apakah meningkatkatkan kasus keguguran dan kelahiran mati (Dashraath et al., 2020). Hasil penelitian yang dilakukan oleh (Schwartz, 2020) didapati 37 ibu hamil yang terkonfirmasi COVID-19 melalui PCR tidak ditemukan pneumonia berat dan atau kematian maternal, diantara 30 neonatus yang dilahirkan tidah ditemukannya kasus yang terkonfirmasi COVID-19.

Covid-19 adalah sebuah virus yang menyerang system pernapasan manusia. Imunitas yang kuat sangat dibutuhkan untuk mencegah terinfeksi dari Covid-19. Perasaan cinta dan kasih sayang melepaskan hormoneendhorpin dan oksitosin yang mana menciptakan kebahagiaan dan memperkuat system imun tubuh. Mindfullness merupakan suatu kondisi kesadaran pada saat ini dengan penuh penerimaan sehingga perlu dilakukan pelayanan kesehatan yang bersifat Holistik yang mencakup Fisik, psikologis dan spriritual . Berdasarkan beberapa jurnal penelitian, perasaan cinta memicu produksi interferon protein yang dapat digunakan untuk bermanfaat untuk meningkatkan imun tubuh, termasuk dalam pencegahan virus Covid-19 sehingga persiapan persalinan normal pada ibu di masa covid-19 ini tidak hanya berfokus pada persiapan secara fisik tapi juga persiapan mental dan spiritual (Alderic, 2019).

Psikologis atau kesehatan jiwa berasal dari tubuh yang secara jasamaniah memberikan kontribusi untuk beberapa aktifitas. Aktifitas psikis ini berinteraksi dengan amigdala, hipotalamus, dan anterior gyruscingulate sehingga menyebabkan diproduksinya adrenalin, neuroendocrinological yang mana menyebabkan masalah di 
tubuh manusia. Bersumber dari psikis/jiwa ini maka menimbulkan penyakit fisik berupa penyakit pernapasan, kardiovaskuler, neuroendokrin, gastrointestinal, psikologis dan penyakit lainnya (Alderice, 2013).

Hasil studi pendahuluan yang dilakukan di Kabupaten OKU Timur Provinsi Sumatera Selatan menunjukkan hasil masih rendahnya tingkat pengetahuan ibu hamil tentang persiapan persalinan, termasuk persipan fisik, psikologis dan spiritual ibu hamil di masa pandemic covid 19 .

\section{MASALAH}

Adapun yang menjadi kendala dan permasalahan yang timbul di masyarakat adalah masih kurangnya pengetahuan masyarakat tentang persiapan persalinan yang meliputi persiapan persalinan dengan protokol keehatan, persiapan fisik, psikologis dan spiritual di masa kenormalan baru (New Normal) sebagai upaya pencegahan Covid-19 dan menciptakan proses persalinan yang aman dan nyaman. Selain itu, informasi tentang covid-19 yang saat ini tersebar di masyarakat juga telah menimbulkan rasa cemas bagi masyarakat sehingga dikhawatirkan dapat berpengaruh kepada penurunan imunitas dan kekebalan tubuh yang dimiliki mereka sehingga lebih rentan terkena permasalahan kesehatan. Jumlah ibu hamil yang akan mendapatkan edukasi tentang persiapan persalinan di masa pandemic covid 19 direncanakan berjumlah 24 orang

\section{METODE PELAKSANAAN}

Pelaksanaan Pengabdian masyarakat ini dilakukan melalui beberapa tahap:

\section{Perizinan}

Perizinan Pendidikan Kesehatan tentang Edukasi Persiapan Persalinan Dengan Protokol Kesehatan Di Masa Kenormalan Baru (New Normal) Sebagai Upaya Pencegahan Covid-19 dilakukan setelah menentukan tempat, sasaran penyuluhan

yaitu di Kabupaten OKU Timur. Perizinan dilakukan kepada beberapa pihak dari kepala desa dan penanggung jawab posyandu yaitu Bidan Desa sebagai mitra kerjasama dalam pelaksanaan kegiatan

\section{Persiapan Kegiatan}

Persiapan penyuluhan dimulai dengan memastikan sasaran khususnya dalam hal jumlah peserta. Tempat dan media dipersiapkan sesuai dengan kebutuhan serta antisipasi kemungkinan masalah yang terjadi. Tempat pelaksanaan pendidikan kesehatan adalah rumah responden masing-masing dan media penyuluhan yang dipersiapkan untuk mempermudah proses pemahaman sasaran sehingga tujuan kegiatan dapat tercapai secara optimal yaitu berupa leaflet.

\section{Pelaksanaan Kegiatan}

Kegiatan pendidikan kesehatan ini dilakukan pada tanggal 24 -28 Februari 2021 bertempat di rumah masyarakat yang menjadi responden di Kabupaten OKU Timur. Tahap pelaksanaan kegiatan meliputi pengisian daftar hadir, pembukaan, pembagian kuisioner pretest, penyampaian materi dan pembagian leaflet, diskusi/ Tanya jawab, pembagian, kuisioner posttest, penutup 


\section{Evaluasi Kegiatan}

Evaluasi dilakukan untuk mengetahui efektifitas kegiatan pendidikan kesehatan. Evaluasi ini dilakukan dengan pengisian kuisioner pretest dan postest tentang persiapan persalinan dengan protokol kesehatan di masa kenormalan baru (new normal) sebagai upaya pencegahan Covid-19. Dari hasil evaluasi awal didapatkan hasil masih rendahnya pengetahuan masyarakat tentang persiapan persalinan dengan protokol kesehatan di masa kenormalan baru (new normal) sebagai upaya pencegahan Covid-19 dengan rata-rata sebesar 20\%

\section{PEMBAHASAN}

Kegiatan Pengabdian Masyarakat ini diadakan bertujuan untuk meningkatkan pengetahuan ibu hamil tentang kebutuhan selama kehamilan. Dari kegiatan yang telah dilaksanakan, terlihat peserta tampak antusias dalam mengikuti kegiatan. Peserta yang hadir sebanyak 24 ibu hamil dengan usia kehamilan yang beragam. Peningkatan pengetahuan peserta dapat diketahui melalui perbandingan hasil pretest dan posttest yang diajukan secara lisan sebelum dan sesudah dilakukannya pendidikan kesehatan.

Pendidikan kesehatan yang disampaikan meliputi:

\section{Persiapan Protokol Kesehatan}

Cuci tangan dengan sabun dan air mengalir sedikitnya selama 20 detik dan bisa menggunkanhandsanitizerberbasis alkohol 70\%, Hindari menyentuh mata, hidung dan mulut dengan tangan yang belum dicuci, sebisa mungkin hindari kontak dengan orang yang sedang sakit, saat mengunjungi rumah bersalin tetap gunakan masker, tutupi mulut dan hidung saat batuk atau bersin dengan tisue, bersihkan dan lakukan penyemproan desinfeksi secra rutin kebagian benda yang sering disentuh, ibu tetap bersalin difasilitas pelayanan kesehatan, segera ke fasilitas kesehatan apabila ada tanda tanda persalinan, rujukan terencana untuk ibu hamil berisiko. Tempat penolongan persalinan ditentukan berdasarkan kondisi ibu sesai dengan level fasyankes pelayanan pertolongan persalinan dan status ibu yang ODP, PDP, terkonfimasi COVID-19 atau bukan, Ibu dengan status ODP, PDP, terkonfimasi COVID-19 bersalin dirumah sakit rujukan, ibu dengan status BUKANODP, PDP, terkonfimasi COVID-19 bersalin difasyankes sesuai kondisi kebidanan, saat merujuk harus sesuai dengan prosedur pecegahanCOVID-19, pelayanan KB pasca persalinan tetap dilakukan sesuai prosedur dan diutamkanmenggunkan MKJP.

\section{Persiapan Fisik, Psikologis, Dan Spiritual Pada Ibu Hamil Dan Ibu Bersalin}

Makan-makanan yang bergizi dan minum yang cukup banyak, serta tetap melakukan aktivitas seperti berjalan pagi, atau kegiatan rumah lainnya, dan tetap istirahat yang cukup, mengikutsertakan keluarga untuk memberikan dorongan moril, cepat tanggap terhadap kebutuhan ibu serta memberikan bimbingan untuk berdoa sesuai agamadan keyakinan.Terapi spiritual dengan memperbanyak ibadah seperti shalat, dzikir, membaca alquran dan ibadah lainnya. Agar membuat ibu dan janin lebih tenang dalam menghadapi kehamilannya.Terapi holistik seperti, murotal al-qur'an, kompres hangat dan kompres dingin, prenatal hypnoterapi, senam hamil, prenatal yoga, dan pregnancy massage yang berguna untuk mengurangi stres, meningkatkan kualitas tidur, memperlancar sirkulasi darah, serta menciptakan rasa aman dan nyaman pada ibu hamil. 
Kegiatan pengabdian masyarakat ini dilaksanakan pada tanggal 24-28Febuari 2021 di Kabupaten OKU Timur. Peningkatan pengetahuan sangat berpengaruh pada perubahan pola dan gaya hidup terhadap kesehatan ibu selama kehamilan.

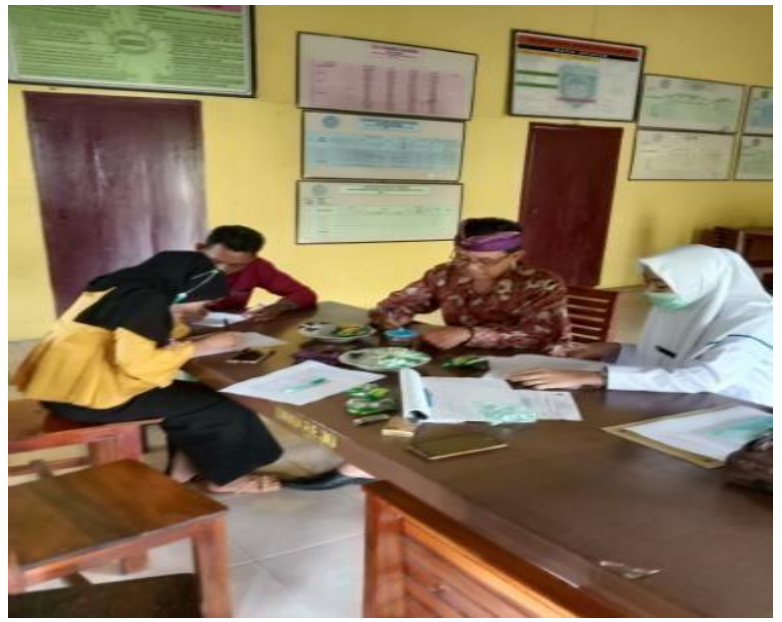

Gambar 1

Koordinasi awal dengan Kepala Desa
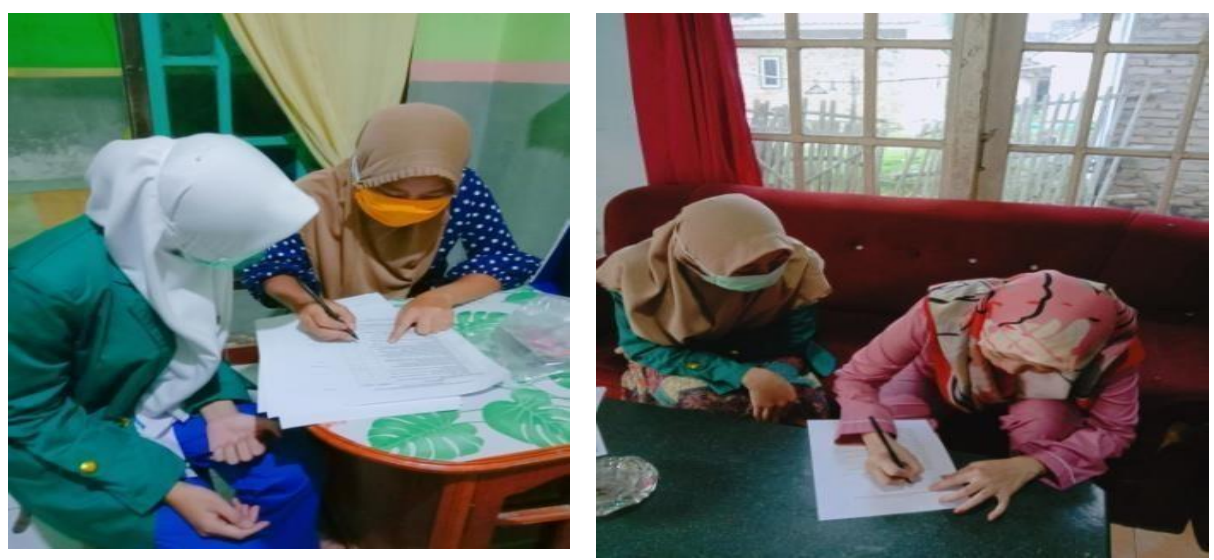

Gambar 2

Pengisian Kuesioner
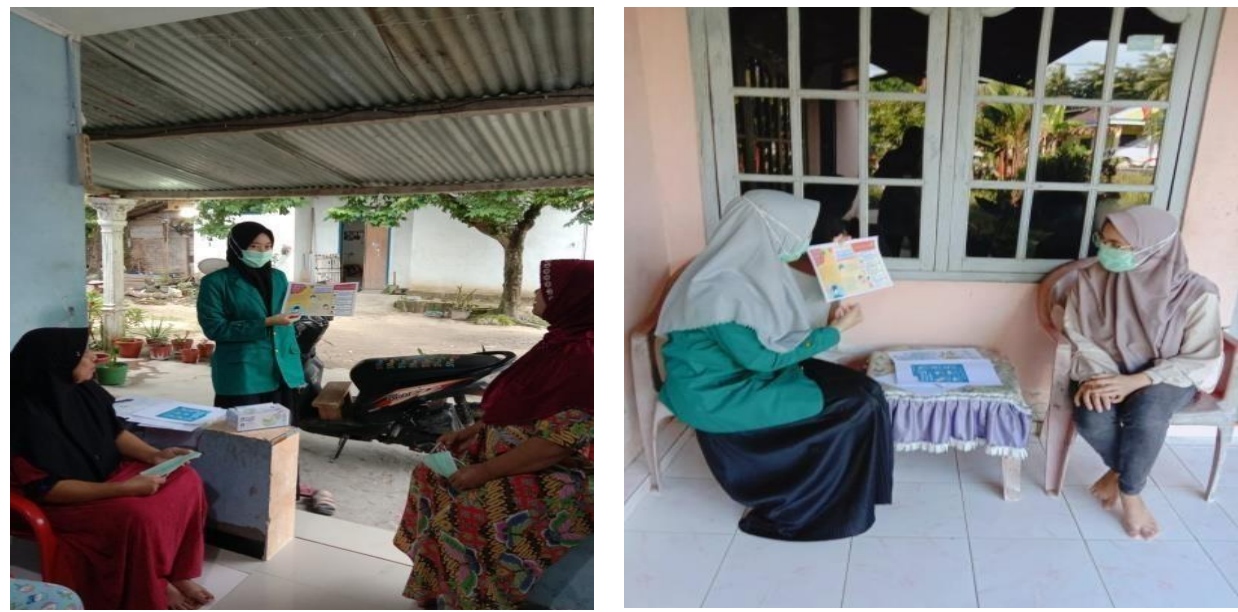

Gambar 3

Pendidikan Kesehatan Persiapan Persalinan 


\section{KESIMPULAN}

Adanya peningkatan pengetahuan masyarakat khususnya ibu hamil mengenai persiapan persalinan, termasuk persipan fisik, psikologis dan spiritual ibu hamil di masa pandemi covid 19

\section{UCAPAN TERIMA KASIH}

Ucapan terima kasih kepada Rektor IKesTMuhammadiyah Palembang beserta jajarannya, LP2MI IKesTMuhammadiyah Palembang, Program studi DIII Kebidanan IKesTMuhammadiyah Palembang, Bupati dan seluruh warga OKU Timur yang telah berpartisipasi aktif dalam kegiatan ini

\section{DAFTAR PUSTAKA}

American Conggress of Obstetricians and Gynecologists. (2017). Guidelines for Perinatal Care

Alderdice, F., Health, P., Mcneill, J., Lynn, F., \& Children, I. (2013). A systematic review of systematic reviews of interventions to improve maternal mental health and well-being. Midwifery, 29(4), 389-399. https://doi.org/10.1016/j.midw.2012.05.010

Dashraath, P., Wong, J. L. J., Lim, M. X. K., Lim, L. M., Li, S., Biswas, A.,Choolani, M., Mattar, C., \& Su, L. L. (2020). Coronavirus disease 2019(COVID-19) pandemic and pregnancy. American Journal of Obstetrics andGynecology. https://doi.org/10.1016/j.ajog.2020.03.021

Gugus Tugas Penanganan COVID-19 RI. (2020). Data Covid-19. Beranda Covid19.Go.Id. https://covid19.go.id/

Kemenkes RI. Pedoman Kesiapsiagaan Menghadapi Infeksi Novel Coronavirus (2019-nCov). Direktorat Jendral Pencegahan dan Pengendalian Penyakit. 2020

Liang, H., \&Acharya, G. (2020). Novel corona virus disease (COVID-19) in pregnancy: Whatclinicalrecommendationstofollow?

Acta ObstetriciaetGynecologicaScandinavica.https://doi.org/10.1111/aogs.13836

POGI. Rekomendasi Penanganan Infeksi Virus Corona (Covid-19) Pada Maternal (Hamil, Bersalin Dan Nifas). Indonesia: POGI. 2020.

Pradana, A. A., Casman, C., \& Nur'aini, N. (2020). Pengaruh Kebijakan Social Distancing pada Wabah COVID-19 terhadap Kelompok Rentan di

Indonesia. Jurnal Kebijakan Kesehatan Indonesia : JKKI, 09(02), 61-67. https://doi.org/10.22146/JKKI.55575

Qiao, J. (2020). What are the risks of COVID-19 infection in pregnant women? The Lancet, 395, 760-762. https://doi.org/10.1016/S0140-6736(20)30365-2

Schwartz, D. A. (2020). An analysis of 38 pregnant women with COVID-19, their newborn infants, and maternal-fetal transmission of SARS-CoV-2: Maternal coronavirus infections and pregnancy outcomes. Archives of Pathology andLaboratory Medicine. https://doi.org/10.5858/arpa.2020-0901-SA

Yang, H., Wang, C., \& Poon, L. C. (2020). Novel coronavirus infection and pregnancy. Ultrasound in Obstetrics and Gynecology, 55, 435-437. https://doi.org/10.1002/uog.22006 